\title{
STICHTING STUDIECENTRUM VOOR ADMINISTRATIEVE AUTOMATISERING
}

\section{De Faculteit der Economische Wetenschappen van de Universiteit van}

Amsterdam heeft het initiatief genomen tot oprichting van een stichting Studiecentrum voor administratieve automatisering.

Het doel van de stichting is het onderzoeken van en het verbreden van kennis omtrent de automatisering van de administratieve arbeid - de verzameling en verwerking van gegevens in de meest ruime zin daaronder begrepen - van ondernemingen, overheidsinstellingen en andere huishoudingen. Met deze doelstelling tracht de stichting te voldoen aan de in steeds sterker mate gevoelde behoefte aan wetenschappelijk verantwoord onderzoek, aan objectieve voorlichting en aan opleiding van verschillende categorieën van deskundigen op dit gebied.

Het ligt in de bedoeling, dat de stichting, naast het verrichten van onderzoekings- en documentatiewerkzaamheden, bijzondere aandacht zal schen_ ken aan voorlichting en opleiding, zowel van studerende aan academische instellingen als van degenen, die in de praktijk bij het vraagstuk zijn betrokken. Daartoe zullen o.a. voordrachten-reeksen worden georganiseerd, waarin een eerste oriëntatie over het onderwerp plaatsvindt, speciaal af. gestemd op de behoeften van accountants_ en organisatie-adviseurs. Daarnaast zullen cursussen van langere duur, waarin nader op de problematiek van de administratieve automatisering wordt ingegaan, en cursussen voor degenen, die zich op dit terrein willen specialiseren, worden ingericht.

Het beheer der stichting is opgedragen aan een Algemeen Bestuur. Van dit bestuur worden tenminste twee leden door de Faculteit der Economische Wetenschappen der Universiteit van Amsterdam en twee leden door het Nederlands Instituut van Accountants aangewezen als hun vertegenwoordigers. Aan academische en niet-academische instellingen, die zich bewegen op terreinen, die binnen de doelstelling van de stichting vallen en aan de arbeid van de stichting deelnemen, kan door het in functie zijnde Algemeen Bestuur het recht worden toegekend een of twee vertegenwoordigers in het Algemeen Bestuur aan te wijzen. De samenstelling van het Algemeen Bestuur van de stichting is thans als volgt:

Prof. Dr. H. J. van der Schroeff

H. P. van den Aardweg Czn., ec. drs.

Mr. J. A. Berger

P. C. Breek

Prof. A. Goudeket

Dr. A. Th. de Lange

H. Reinoud

Prof. A. M. van Rietschoten

H. C. Treffers

R. W. Starreveld

Het is de bedoeling het bestuur een zo breed mogelijke vertegenwoordiging te doen zijn van alle personen en instellingen die zich met het vraagstuk van de administratieve automatisering bezighouden. Hiertoe ligt een uitbreiding van het bestuur met vertegenwoordigers van daarvoor in aanmerking komende instellingen en bedrijven in het voornemen.

De algemene leiding van de onderzoekingen, cursussen en overige werkzaamheden van het studiecentrum berust bij een of meer directeuren. Als zodanig zijn door het Bestuur aangewezen de heren R. W. Starreveld en A. B. Frielink, beiden lector in de administratieve organisatie aan de Universiteit van Amsterdam.

De stichting is voorlopig gevestigd in het gebouw van de Universiteit van Amsterdam, Oudemanhuispoort 4-6, Amsterdam-C. 